\title{
Smartphone Dependence among Undergraduates in Taiwan
}

\author{
Nae-Fang Miao ${ }^{1}$, Cheng-Jin Lin ${ }^{2}$, Ching-Lien Cheng ${ }^{3}$, \\ Yu-Ling $\mathrm{Hsiao}^{4}$ and I-Hui Chen ${ }^{5}$
}

\author{
${ }^{1}$ Assistant Professor, RN, PhD, Post-Baccalaureate Program in Nursing, \\ College of Nursing, Taipei Medical University, No. 250, Wuxing Street, \\ Taipei City 11031, Taiwan \\ ${ }^{2}$ MS, Master Program in Long-term Care, College of Nursing, \\ Taipei Medical University, No. 250, Wuxing Street, Taipei City 11031, Taiwan \\ ${ }^{3}$ RN, Head Nurse, Cathay General Hospital No. 280, Renai Rd. Sec. 4, Taipei City \\ 10630, Taiwan \\ ${ }^{4}$ Assistant Professor, RN, PhD, School of Nursing, College of Medicine, \\ Fu Jen Catholic University, No. 510, Zhongzheng Rd, Xinzhuang Dist., \\ New Taipei City 24205, Taiwan \\ ${ }^{5}$ Assistant Professor, RN, PhD, Master Program in Long-term Care, College of \\ Nursing, Taipei Medical University, No. 250, Wuxing Street, \\ Taipei City 11031, Taiwan \\ E-mail:naefang@tmu.edu.tw; cjlin0616@gmail.com; cutelien408@gmail.com; \\ 125602@mail.fju.edu.tw; ichen4@tmu.edu.tw
}

\author{
Received 5 June 2017; Accepted 4 April 2018; \\ Publication 7 May 2018
}

\begin{abstract}
Journal of Mobile Multimedia, Vol. 14_2, 231-256.

doi: 10.13052/jmm1550-4646.1424

(c) 2018 River Publishers
\end{abstract}

Smartphones have become a new means of communication and a major method of obtaining information. Dependence on or the excessive use of smartphones may affect health in the long term. However, little attention has been focused on smartphone use and dependence among undergraduates. Therefore, this study investigated the smartphone use behavior of Taiwanese undergraduates and their dependence on smartphones. A cross-sectional study design with a structured questionnaire was used for undergraduates aged $\geq 20$ years from four universities. The results suggested that the majority 
of participants, particularly women, experienced physical discomfort caused by smartphone use. Moreover, the participants exhibited a moderate to high dependence on smartphones. Smartphone use and dependence were both affected by family economic status, monthly allowance, and major. The findings indicated that health care providers, educators, and parents can play critical roles in encouraging the healthy use of smartphones among undergraduates.

Keywords: Smartphone use, Smartphone dependence, Undergraduates, Health, Mobile phone.

\section{Introduction}

Cell phones have undoubtedly changed and affected people's lives. Firstgeneration $(1 \mathrm{G})$ cell phones used analog signals and could transmit only voice. Second-generation $(2 \mathrm{G})$ cell phones were introduced with a more efficient and stable operating system and additional features, such as text messages, a calendar, Bluetooth transmission, and a camera. Third-generation (3G) mobile telecommunication technology enabled cell phones to use a universal wireless communication system and support services including wireless Internet access and multimedia applications [52]. Because of progress in mobile communications and wireless technology, smartphones, using $3 \mathrm{G}$ telecommunication technology, now have access to the Internet, multimedia applications, and data processing systems as well as entertainment features, resulting in a rapid increase in the number of smartphone users, including young people, worldwide over the past few years [19]. For instance, in the United States, the rate of smartphone ownership among people aged 18-24 years increased from $60 \%$ in 2012 to $75 \%$ in 2013 [4]. With Internet services, people can easily and simultaneously communicate with each other, which, in turn, changes social interactions and communication patterns [55, $66,69]$. Nevertheless, because of the excessive use of smartphones, these modern gadgets have negatively influenced physical and psychological wellbeing, for example, by causing loneliness [50], emotional distress [6], and sleeplessness [30]. Empirical studies on smartphone use and dependence have been conducted mainly in Western countries and few related studies have been conducted in Eastern countries, particularly Taiwan. To elucidate this issue, this study examined smartphone use and dependence among the young people in Taiwan. 


\section{Literature Review}

\subsection{Smartphone Use among Taiwanese Young People}

Smartphones were introduced to Taiwan in 2007 and have influenced people's lives through $3 \mathrm{G}$ technology, which offers efficiency, convenience, and mobility [43, 47, 52]. Smartphones have become a new means of communication and a major method of obtaining information in Taiwan [70]. In addition, smartphones make social networking and entertainment sites more usable and accessible $[43,56,70]$. According to a 2011 nationwide report on cell phone use among young people in Taiwan, $80 \%$ had their own cell phone, which was an increase of $20 \%$ compared with $60 \%$ of young people owning a cell phone in 2009. In addition, $93 \%$ of the young people who owned a cell phone felt anxious when their cell phone ran out of battery, when they made a call and the other person did not pick up or their cell phone use was restricted by parents or left at home [24]. The report revealed that young people in Taiwan are vulnerable to the negative effects of using cell phones, including smartphones. Undergraduates are particularly likely to become heavily dependent on their smartphones [34, 41].

Research on smartphone use and dependence among Taiwanese undergraduates is limited. Studies have mainly focused on the Internet behavior and addiction of high school students [11, 16, 25, 36, 58, 60, 67] and Internet addiction disorders and tendencies of college students [12, 17, 40, 62]. Therefore, in this study, we aimed to investigate smartphone use and dependence and thoroughly examine how demographic factors contribute to smartphone use and dependence among undergraduates in Taiwan.

\subsection{Cell Phone Use among Young People}

Using cell phones to manage daily communication and maintain social networks is becoming a necessity for young people [22]. The 2011 report of the Office of Communications, London showed that $65 \%$ of young people checked their cell phone when talking to others, $34 \%$ used a cell phone while eating, and $47 \%$ used a cell phone while bathing or while using restrooms. Furthermore, a report demonstrated that $43 \%$ of all American young people owning a cell phone reported they had talked on a cell phone while driving. In addition, $40 \%$ stated that they had been passengers with drivers who used a cell phone [45]. Smartphones belong to the same information and communication technology as cell phones; therefore, smartphone use should demonstrate similar phenomena and effects. 


\section{Nae-Fang Miao et al.}

Studies have reported the reasons for which young people use cell phones. For instance, Ling and Yttri (2002) reported two factors that contributed to cell phone use, namely microcoordination and hypercoordination [42]. Microcoordination refers to using cell phones to complete a task (e.g., making appointments), whereas hypercoordination is defined as communication for expression, such as chatting. Therefore, young people spend a large amount of time on their phones to facilitate social interactions.

Oulasvirta and the colleagues (2012) reported that undergraduate respondents spent 2.7 hours a day checking emails, Facebook, update feeds, and news headlines by using smartphones [54]. In addition, Balakrishnan and Raj (2012) investigated cell phone use among the students of a Malaysian university on the basis of the uses and gratifications theory [3]. The authors observed that the students used cell phones for socialization and privacy from their parents. The students generally used their cell phones between 5 and 10 times per day.

Kamibeppu and Sugiura (2005) demonstrated that the e-mail applications of cell phones were frequently used by students in Japan, with the majority of students exchanging e-mails with schoolmates $>10$ times a day. The students preferred to email through cell phones instead of direct communication because they found it easier to express their feelings [31]. By contrast, Brown, Campbell and Ling (2011) revealed that young people in the United States were likely to use the text messaging feature of cell phones to communicate with peers, with 100 text messages sent per day [9]. Moreover, undergraduates who excessively used cell phones were inclined to report physical problems, such as prolonged sleep, sleeplessness, headache, and muscular soreness $[13,30]$.

The duration of cell phone ownership and the amount of money spent each month on cell phones are indicators of cell phone use. Young people spend increasing time using cell phones as the duration of ownership increases. Cell phone ownership is positively associated with the number of calls received and feeling that a cell phone is a necessity in daily life [1]. In addition, the monthly cell phone expenditure has a positive relationship with cell phone use [59]. Financially constrained people believe that the main barrier to increased cell phone use is the cost; therefore, they reduce the cost of cell phone use by making few outgoing calls, misscalling $[3,21]$, or using prepaid services [26]. Wilska (2003) demonstrated that parents generally paid the cell phone bills of their children [68]. However, Coogan and Kangas (2001) revealed that parents typically limited the bill amount to prevent their children from using cell phones excessively, thereby influencing the patterns of mobile use in the young people [18]. 
Young people were shown to use cell phones while driving [65]. Furthermore, Nemme and White (2010) revealed that young people preferred to read text messages than send text messages while driving because the behavior of sending text messages is less accepted by society [53]. Consequently, the number of text messages sent was less than that received while driving.

Researchers have also investigated how user demographics influence cell phone use patterns. Gender differences in cell phone use were revealed; female university students were more likely to make calls for social interaction [69] and regularly have conversations over cell phones [5,63]. Affordability affects cell phone use; young people in high-income households were more likely to use cell phones [23, 41, 59]. Moreover, young people with a higher monthly allowance were more likely to use cell phones [23].

Based on the aforementioned studies, the first research question of this study was proposed as follows:

RQ1: How do the characteristics of Taiwanese students influence their smartphone use?

\subsection{Cell Phone Dependence Among Young People}

Smartphone use has sparked the "phubber" phenomenon. "Phubbers" ignore people who are actually present in a social setting because they use a smartphone excessively, which, in turn, leads to various concerns, including dependence. According to the Diagnostic and Statistical Manual of Mental Disorders, Fourth Edition, Text revision (DSM-IV-TR), substance abuse includes behavioral and physical dependence [2]. Behavioral dependence refers to substance-seeking activities and the related evidence of pathological use patterns; physical dependence is defined as the physical effects of multiple episodes of substance use, including tolerance and withdrawal. Accordingly, dependence on information technology, such as cell phones and the Internet, is considered behavioral dependence because of the nonchemical human-machine interaction [7, 10]. In addition, technological dependence has characteristics such as intensive use, a craving for technology-related activities, lack of impulse control, mood instability, tolerance, abstinence, interpersonal conflicts, recurrence [27, 28, 72], and poor time management [8]. Oulasvirta et al. (2012) demonstrated that spending 3 hours per day with smartphones would interfere with daily routine [54]. In addition, studies have revealed that people who consider themselves dependent on cell phones are more likely to be depressed [71] and lonely [61]. 
Research has shown that demographics influence dependence on smartphones. For instance, Morahan-Martin and Schumacher (2000) showed that male college students were likely to use applications such as Internet games and consequently have problematic use of computer technology [50]. Women have a higher level of dependence on cell phones than men do [39,63], possibly because the female attitude toward computer technology has become more positive [57]. In addition, the monthly allowance and household income [39] and the major in which students studied [38] were positively associated with cell phone dependence.

Based on the aforementioned studies, the second research question of this study was proposed as follows:

RQ2: How do the characteristics of Taiwanese students influence their smartphone dependence?

\section{Methods}

\subsection{Design}

This cross-sectional study employed a structured questionnaire to collect data. Before collecting data, the study protocol was approved by the Institutional Review Board of authors' university, which waived the need for a written consent. The researchers first contacted the administrative units of universities for permission and arranged to collect data. The researchers then personally explained the research purposes, questionnaire content, and instructions to complete the questionnaire to the target students. After obtaining their verbal consent, the students were given the questionnaire and an envelope used to maintain the students' privacy. During data collection, the participants could quit at any time if they felt uncomfortable or were unwilling to answer the questions. To increase the number of completed questionnaires, the participants received an incentive to compensate them for their time and effort. Finally, the researchers collected the envelopes containing the completed questionnaires at the end of the test.

\subsection{Participants}

In 2012, there were 436,812 Taiwanese undergraduates including 225,216 men and 211,596 women, aged over 20 years [48]. According to the sampling method of Krejcie and Morgan (1970), with a 95\% confidence level and 
a 5\% margin of error, the minimum sample size for this study should be 385 participants [33]. This study used convenience sampling to collect data from four universities in Northern Taiwan during the period from October to December 2013. A total of 397 students were approached and they returned the questionnaires. Among them, 22 were excluded because they did not own a smartphone. Finally, 375 students, whose ages ranged from 20 to 24 years, were included because they completed the questionnaire and were valid for analysis (completion rate $=94 \%$ ).

\subsection{Instruments}

The contents of the self-administered structured questionnaire were based on the foreign and domestic literature. Six experts in public health, health education, and health care professions were invited to examine the relevancy, appropriateness, necessity, and clarity of the questionnaire. The questionnaire was also reviewed and modified according to the item-level content validity index (I-CVI) [44]. The majority of I-CVI values ranged from 0.83 to 1.00 . Only 4 items regarding dependence on smartphones had I-CVI values of 0.66. These 4 items were modified according to the opinions of the experts. Moreover, a pilot test $(\mathrm{n}=43)$ was conducted on September 13, 2013 at a university in Northern Taiwan to establish the reliability of the scale of dependence on smartphones. The pilot test results showed that the Cronbach's $\alpha$ of the scale was 0.92 . The contents of the final questionnaire are described as follows.

\subsubsection{Smartphone use}

To assess smartphone use patterns, 5 items were included in this section: the duration of using a smartphone, monthly cost of using a smartphone, payer of the smartphone bill, use of a smartphone while driving a car or scooter, and experience of physical discomfort (e.g., myofascial pain syndrome, dry eye syndrome, or joint pains) because of using a smartphone. The duration of using a smartphone was categorized from $<1$ year to $>5$ years. Smartphone cost per month included choices from $\leq$ NT $\$ 300$ to $\geq$ NT $\$ 3,001$. The payer of the smartphone bill included "self," "parents," "siblings," "other relatives," and "boyfriend or girlfriend." Regarding the items "had used a smartphone while driving a car or a scooter" and "had experienced physical discomfort," respondents were asked to respond either "yes" or "no." 


\subsubsection{Dependence on smartphones}

To assess the level of dependence on smartphones, this scale included 25 items, with a 5 -point Likert scale $(1=$ strongly disagree; $5=$ strongly agree), that included tolerance for smartphone use, compulsive smartphone use, withdrawal, social interactions, and self-management, which were based on the literature [35, 64]. The total possible score ranged from 25-125, with a higher score indicating a higher level of dependence on smartphones. Tolerance for smartphone use was measured by 4 items. An example item was "I realize that I spend more time using a smartphone now than I did 3 months ago." Compulsive smartphone use was measured by 6 items. An example item was "I cannot control my impulse to use a smartphone." Withdrawal was measured by 4 items. An example item was "I feel anxious when there is no signal." Social interactions were measured by 5 items. An example item was "I feel I got more friends after I started using a smartphone." Selfmanagement was measured by 6 items. An example item was "I often have difficulty staying on my schedule due to use of a smartphone." In this study sample, the Cronbach's $\alpha$ for dependence on smartphones was 0.92 , indicating satisfactory internal consistency.

\subsubsection{Demographics}

Participants reported four characteristics: gender, the major in which they studied, monthly allowance, and monthly household income. Gender was coded as male or female. The majors included Medical Science and Engineering, Management and Business, and Liberal Arts and Foreign Languages. The item assessing monthly allowance included choices ranging from "none" to $\geq$ NT $\$ 12,001$. Monthly household income was reported from "none" to $\geq$ NT $\$ 150,001$.

\section{Analysis}

Statistical Analysis System (SAS, version 9.3; SAS Institute Inc., Cary, NC, USA) was used to analyze statistical data. A chi-square test was used to compare participant characteristics and smartphone use; however, several variables had values of $<5$. Based on Munro's (2004) principles, the variables were collapsed to form dichotomous or fewer measures, including years of smartphone use ( $<3$ years and $\geq 3$ years), smartphone cost per month $(\leq \mathrm{NT} \$ 500$ and $>$ NT $\$ 500$ ), bill payer ("parents" and "self or other relatives"), monthly allowance $(\leq \mathrm{NT} \$ 6,000$, NT\$6,001-9,000, and $\geq \mathrm{NT} \$ 9,001)$, and monthly household income $(\leq \mathrm{NT} \$ 50,000, \mathrm{NT} \$ 50,001-100,000$, and $\geq \mathrm{NT} \$ 100,001)$ 
$[51,64]$. At test and analysis of variance (ANOVA) with pairwise comparisons, using the Sidak method, were used to analyze participant characteristics and smartphone dependence. Scheffe's post hoc test and Fisher's protected least significant difference (LSD) test were also used. The significance level was set at $\mathrm{p}<0.05$.

\section{Results}

\subsection{Descriptive Results}

The overall participation rate was higher for women $(62.40 \%)$ than for men (37.60\%). Most of the participants belonged to a college of Medical Science, and Engineering (39.73\%); had a monthly household income of NT \$50,001-80,000 (24.27\%; in 2013, the average exchange rate was US\$1 $\approx$ NT\$29.75); and had a monthly allowance of NT\$6,001-9,000 (29.33\%) (Table 1).

Among the participants, $62.14 \%$ had used a smartphone for $\geq 1$ years, $<3$ years. Most of the participants (39.74\%) paid NT\$501-1,000 for their monthly phone bill, and most of the phone bills (74.67\%) were paid by parents. Furthermore, although $64.00 \%$ of the participants stated that they never used a smartphone while driving a car or scooter, $36 \%$ of participants had used a smartphone while driving a car or scooter. Approximately $76 \%$ of the participants experienced physical discomfort because of using a smartphone. The mean value of dependence on smartphones within the past 3 months was 73.42 (standard deviation $(\mathrm{SD})=16.54$; range $=$ 25-125), indicating a moderate to high level of dependence on smartphones (Table 2).

\subsection{Relationships between Participant Characteristics and Smartphone Use}

Table 3 shows statistically significant differences between gender and having used a smartphone while driving a car or scooter $(\chi 2=6.23, \mathrm{p}=0.013)$ and experiencing physical discomfort $(\chi 2=10.79, \mathrm{p}=0.001)$; between major and smartphone cost per month $(\chi 2=6.00, \mathrm{p}=0.049)$ and having used a smartphone while driving a car or scooter $(\chi 2=6.86, \mathrm{p}=0.032)$; between monthly allowance and years of smartphone use $(\chi 2=12.68, \mathrm{p}=0.002)$ and smartphone cost per month $(\chi 2=14.60, \mathrm{p}<0.001)$; between monthly allowance and the smartphone bill payer $(\chi 2=8.53, \mathrm{p}=0.014)$ and having used a smartphone while driving a car or scooter $(\chi 2=7.81, \mathrm{p}=0.020)$; 
Table 1 Item content validity index (CVI)

\begin{tabular}{|c|c|}
\hline Items & CVI \\
\hline \multicolumn{2}{|l|}{ Smartphone use } \\
\hline 1. How much time do you spend on smartphone per day? & 0.83 \\
\hline 2. How much is for your smartphone bill per month? & 0.83 \\
\hline 3. Who pays for your monthly bill of smartphone? & 1.00 \\
\hline 4. Have you ever used a smartphone while driving a car or scooter? & 0.83 \\
\hline $\begin{array}{l}\text { 5. Had you experienced negative physical symptoms (e.g., myofascial pain } \\
\text { syndrome, dry eye syndrome, or joint pains) after using smartphones? }\end{array}$ & 0.83 \\
\hline \multicolumn{2}{|l|}{ Tolerance for smartphone use } \\
\hline 6. I realize that I spend more time using a smartphone. & 1.00 \\
\hline 7. I realize that the frequency of my using a smartphone is higher. & 1.00 \\
\hline 8. I feel more urge to use my smartphone again right after I stopped using it. & 1.00 \\
\hline 9. I feel that I use my smartphone longer. & 0.66 \\
\hline \multicolumn{2}{|l|}{ Compulsive smartphone use } \\
\hline 10. I cannot control my impulse to use a smartphone. & 1.00 \\
\hline $\begin{array}{l}\text { 11. I bring my smartphone to the rest room even when I am in a hurry to get } \\
\text { there. }\end{array}$ & 1.00 \\
\hline 12. I use my smartphone even if I am in class. & 1.00 \\
\hline 13. I lack adequate sleep due to excessive smartphone use. & 1.00 \\
\hline 14. I turn on my smartphone for 24 hours. & 1.00 \\
\hline 15. I check my smartphone when I just wake up every morning. & 0.66 \\
\hline \multicolumn{2}{|l|}{ Withdrawal } \\
\hline 16. I feel anxious when there is no signal. & 1.00 \\
\hline 17. I feel anxious when my smartphone battery is running out. & 1.00 \\
\hline 18. I feel upset when I am not using my smartphone. & 1.00 \\
\hline 19. I can get rid of tiredness with smartphone use. & 1.00 \\
\hline \multicolumn{2}{|l|}{ Social interactions } \\
\hline 20. I feel I got more friends after I started using a smartphone & 1.00 \\
\hline 21. All of my friends are using smartphones. & 1.00 \\
\hline $\begin{array}{l}\text { 22. I feel I cannot stay connected to social networks if not using my } \\
\text { smartphone. }\end{array}$ & 1.00 \\
\hline $\begin{array}{l}\text { 23. I feel it is easier to connect with friends via my smartphone than via } \\
\text { face-to-face. }\end{array}$ & 0.66 \\
\hline 24. I always neglect my real-life friends due to smartphone use. & 1.00 \\
\hline \multicolumn{2}{|l|}{ Self-management } \\
\hline 25. I often have difficulty staying on my schedule due to use of a smartphone & 1.00 \\
\hline 26. I feel pain at the back of the neck while using a smartphone. & 1.00 \\
\hline 27. I feel my life would be boring without smartphone use. & 0.83 \\
\hline 28. I feel I spend a lot of money on monthly bill of my smartphone. & 0.66 \\
\hline 29. I try to hide what I have been up to in relation to my smartphone. & 0.83 \\
\hline
\end{tabular}

and between monthly household income and years of smartphone use $(\chi 2=$ $17.71, \mathrm{p}<0.001)$ and having used a smartphone while driving a car or scooter $(\chi 2=9.58, p=0.008)$. 
Table 2 Participant characteristics $(N=375)$

\begin{tabular}{|c|c|c|c|}
\hline Characteristics & Category & $N$ & Percentage (\%) \\
\hline \multirow[t]{2}{*}{ Gender } & Male & 141 & 37.60 \\
\hline & Female & 234 & 62.40 \\
\hline \multirow[t]{3}{*}{ Major } & $\begin{array}{l}\text { Medical Science and } \\
\text { Engineering }\end{array}$ & 149 & 39.73 \\
\hline & Management and Business & 121 & 32.27 \\
\hline & $\begin{array}{l}\text { Liberal Arts and Foreign } \\
\text { Languages }\end{array}$ & 105 & 28.00 \\
\hline \multirow{8}{*}{$\begin{array}{l}\text { Monthly household } \\
\text { income }^{\mathrm{a}}(\mathrm{NT} \$)^{\mathrm{b}}\end{array}$} & None & 15 & 4.00 \\
\hline & $\leq 18,000$ & 23 & 6.13 \\
\hline & $18,001-35,000$ & 41 & 10.93 \\
\hline & $35,001-50,000$ & 67 & 17.87 \\
\hline & $50,001-80,000$ & 91 & 24.27 \\
\hline & $80,001-100,000$ & 61 & 16.27 \\
\hline & $100,001-150,000$ & 35 & 9.33 \\
\hline & $\geq 150,001$ & 28 & 7.47 \\
\hline \multirow{6}{*}{$\begin{array}{l}\text { Monthly allowance } \\
(\mathrm{NT} \$)^{b}\end{array}$} & None & 14 & 3.73 \\
\hline & $\leq 3,000$ & 28 & 7.47 \\
\hline & $3,001-6,000$ & 104 & 27.73 \\
\hline & $6,001-9,000$ & 110 & 29.33 \\
\hline & $9,001-12,000$ & 79 & 21.07 \\
\hline & $\geq 12,001$ & 40 & 10.67 \\
\hline
\end{tabular}

Note: ${ }^{\mathrm{a}}$ Missing data $=14$.

${ }^{\mathrm{b}}$ In 2013 , the average exchange rate was US $\$ 1 \approx \mathrm{NT} \$ 29.75$.

\subsection{Relationships Between Participant Characteristics and Smartphone Dependence}

Smartphone dependence showed statistically significant differences among the major in which participants studied $(\mathrm{F}=5.85, \mathrm{p}<0.01)$, monthly allowance $(\mathrm{F}=3.37, \mathrm{p}<0.05)$, and monthly household income $(\mathrm{F}=4.25$, $\mathrm{p}<0.05$ ). According to the results of Scheffe's post hoc test, participants from colleges of Management and Business had the highest dependence on smartphones. Participants with a monthly allowance of $\geq N T \$ 9,001$ had the highest dependence on smartphones. Participants whose monthly household income was $\geq$ NT $\$ 100,001$ had a higher dependence on smartphones than those whose monthly household income was NT\$50,001-100,000. On the other hand, participants whose monthly household income was $\leq$ NT $\$ 50,000$ had a higher dependence on smartphones than those whose monthly household income was NT\$50,001-100,000 (Table 4). 
242 Nae-Fang Miao et al.

Table 3 Smartphone use and dependence among participants $(N=375)$

\begin{tabular}{|c|c|c|c|}
\hline Variables & Category & $N$ & Percentage (\%) \\
\hline \multirow[t]{4}{*}{ Years of smartphone use } & $<1$ year & 83 & 22.13 \\
\hline & $\begin{array}{l}\geq 1 \text { years } \\
<3 \text { years }\end{array}$ & 233 & 62.14 \\
\hline & $\begin{array}{l}\geq 3 \text { years } \\
<5 \text { years }\end{array}$ & 50 & 13.33 \\
\hline & $\geq 5$ years & 9 & 2.40 \\
\hline \multirow[t]{6}{*}{ Smartphone cost per month $(\mathrm{NT} \$)^{\mathrm{a}}$} & $\leq 300$ & 56 & 14.93 \\
\hline & $301-500$ & 87 & 23.20 \\
\hline & $501-1,000$ & 149 & 39.74 \\
\hline & $1,001-2,000$ & 73 & 19.47 \\
\hline & $2,001-3,000$ & 8 & 2.13 \\
\hline & $\geq 3,001$ & 2 & 0.53 \\
\hline \multirow[t]{5}{*}{ Smartphone bill payer } & Self & 88 & 23.47 \\
\hline & Parents & 280 & 74.67 \\
\hline & Siblings & 3 & 0.80 \\
\hline & Other relatives & 2 & 0.53 \\
\hline & $\begin{array}{l}\text { Boyfriend or } \\
\text { girlfriend }\end{array}$ & 2 & 0.53 \\
\hline \multirow{2}{*}{$\begin{array}{l}\text { Had used a smartphone while } \\
\text { driving a car or a scooter }\end{array}$} & Yes & 135 & 36.00 \\
\hline & No & 240 & 64.00 \\
\hline \multirow[t]{2}{*}{$\begin{array}{l}\text { Had experienced physical } \\
\text { discomfort }\end{array}$} & Yes & 285 & 76.00 \\
\hline & No & 90 & 24.00 \\
\hline Dependence on smartphones ${ }^{\mathrm{b}}$ & & Mean $=73.42$ & $S D=16.54$ \\
\hline
\end{tabular}

\section{Discussion}

This study assessed smartphone use and dependence among undergraduates in Taiwan. Moreover, this study examined individual factors that have been identified as crucial in information and communication technology use behaviors. In this study, most of the undergraduates had a monthly allowance of NT\$6,001-9,000, which was similar to the results of a national report showing that undergraduates had a monthly allowance of NT\$5,000-10,000 [15]; however, the monthly household income of most of the participants was NT\$50,001-80,000, which was lower than the national average monthly household income of NT $\$ 93,532$ [20]. The difference may have been caused by using convenience sampling in this study. 
Smartphone Dependence among Undergraduates in Taiwan 243






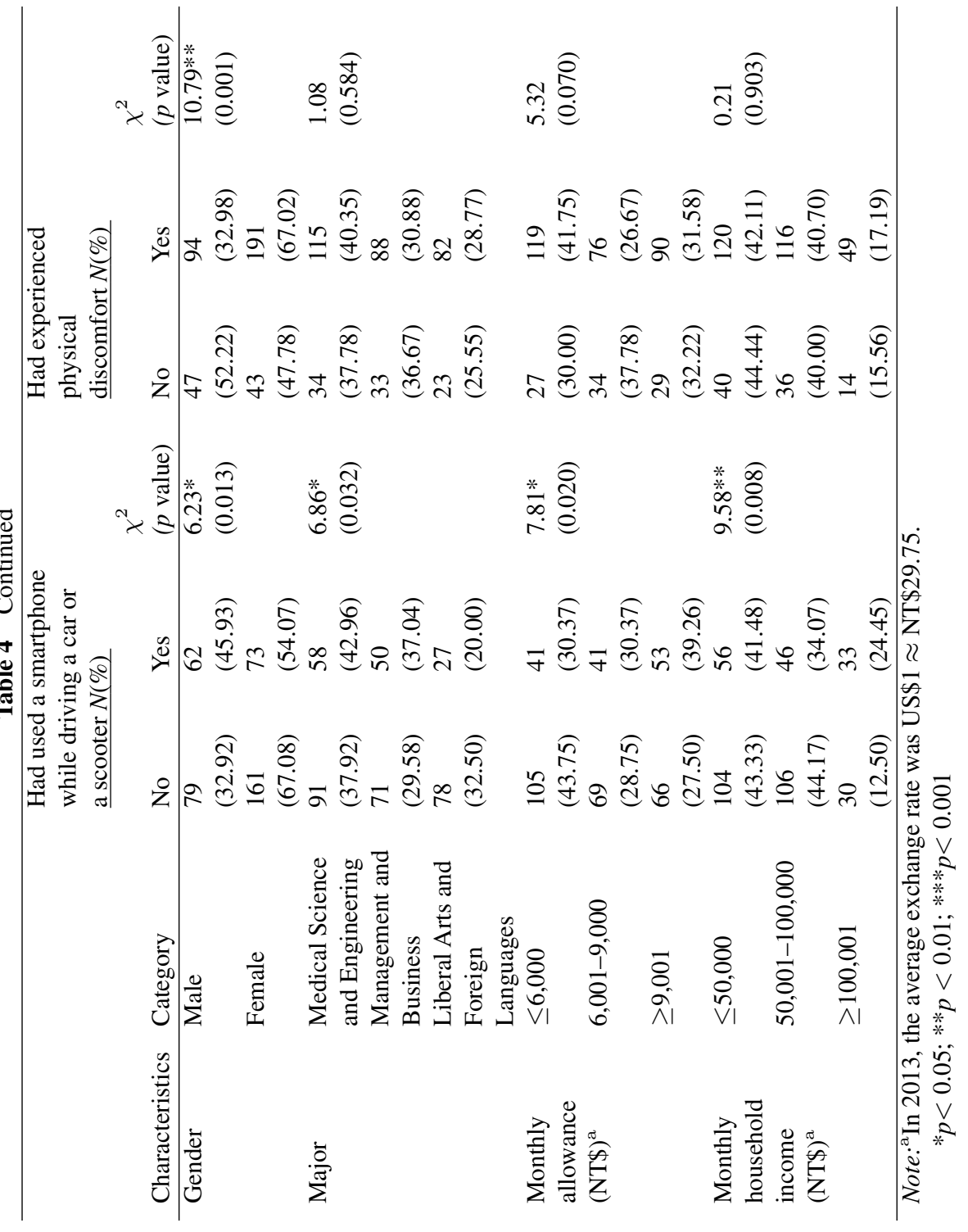


Table 5 T test and ANOVA analysis of participant characteristics and smartphone dependence $(N=375)$

\begin{tabular}{|c|c|c|c|c|c|}
\hline Characteristics & Category & $N$ & $\begin{array}{l}\text { Mean } \\
(\mathrm{SD})^{b}\end{array}$ & F/t Value & $\begin{array}{c}\text { Scheffe's/LSD } \\
\text { Test }\end{array}$ \\
\hline \multirow[t]{2}{*}{ Gender } & 1. Male & 141 & $\begin{array}{c}71.43 \\
(17.10)\end{array}$ & 3.31 & \\
\hline & 2. Female & 234 & $\begin{array}{c}74.62 \\
(16.12)\end{array}$ & & \\
\hline \multirow[t]{3}{*}{ Major } & $\begin{array}{l}\text { 1. Medical Science } \\
\text { and Engineering }\end{array}$ & 149 & $\begin{array}{l}71.18 \\
(16.05)\end{array}$ & $5.85 * *$ & $2>1$ \\
\hline & $\begin{array}{l}\text { 2. Management and } \\
\text { Business }\end{array}$ & 121 & $\begin{array}{c}77.59 \\
(17.24)\end{array}$ & & $2>3$ \\
\hline & $\begin{array}{l}\text { 3. Liberal Arts and } \\
\text { Foreign Language }\end{array}$ & 105 & $\begin{array}{c}72.80 \\
(15.64)\end{array}$ & & \\
\hline \multirow[t]{3}{*}{$\begin{array}{l}\text { Monthly allowance } \\
(\mathrm{NT} \$)^{a}\end{array}$} & $1 . \leq 6,000$ & 146 & $\begin{array}{c}71.49 \\
(16.64)\end{array}$ & $3.37 *$ & $3>1$ \\
\hline & 2. $6,001-9,000$ & 110 & $\begin{array}{c}72.56 \\
(16.59)\end{array}$ & & \\
\hline & 3. $\geq 9,001$ & 119 & $\begin{array}{c}76.59 \\
(16.05)\end{array}$ & & \\
\hline \multirow{4}{*}{$\begin{array}{l}\text { Monthly household } \\
\text { income (NT\$) }\end{array}$} & 1. $\leq 50,000$ & 146 & 75.03 & $4.25 *$ & $3>2$ \\
\hline & & 152 & $(17.70)$ & & $1>2$ \\
\hline & 2. $50,001-100,000$ & & $\begin{array}{c}70.48 \\
(15.68)\end{array}$ & & \\
\hline & 3. $\geq 100,001$ & 63 & $\begin{array}{c}76.41 \\
(14.58)\end{array}$ & & \\
\hline
\end{tabular}

The results showed that several individual factors were correlated with both smartphone use patterns and dependence among the undergraduates. The economic status of the family and the monthly allowance of the student are the two major factors influencing smartphone use by undergraduates. In Taiwan, most undergraduates receive a monthly allowance from their parents; therefore, undergraduates with a higher family income are likely to receive a higher monthly allowance, and, in turn, have more years of experience with smartphones, higher monthly phone bills, and more dependence on smartphones. This finding is consistent with those of previous studies, in which a higher economic status indicated more monthly telecommunication expense, more cell phone use [10,29], and more dependence on smartphones [39]. By contrast, students having a lower monthly allowance are likely 
to have lower monthly smartphone expenses and lower dependence levels. Undergraduates may have a low financial capability to pay bills [13] or those having a lower monthly allowance might effectively use their allowance and control their smartphone use. These findings indicate that restricting undergraduates' allowance might reduce their dependence on smartphones. Therefore, parents should understand and help their children to manage their allowance and smartphone use. If children excessively spend money and time on smartphones, parents can advise the children about the adverse effects of smartphone overuse. Furthermore, research has shown that undergraduates generally have maladaptive behaviors and lack knowledge about dependence and addiction [49]. Health care providers and educators can hold seminars or provide relevant information to students to help students manage their smartphone use.

Similar to the findings of Korpinen and Pääkkönen (2011), we discovered that more women than men reported experiencing physical discomfort caused by using a smartphone [32]. This difference may be explained by the different psychology and physiology of men and women [53, 59]. In addition, although we did not find a statistically significant difference between the two genders with regard to smartphone dependence, female undergraduates had a higher average score of smartphone dependence than male undergraduates did. Accordingly, women might constitute a risk group of people with a high dependence on smartphones and who suffer physical symptoms. Therefore, additional tailored interventions are required to prevent or reduce the adverse health effects of smartphone overuse among female students. Furthermore, we suggest that health care providers, parents, and educators direct students identified as having smartphone dependence to obtain appropriate treatment as well as play major roles in preventing smartphone dependence by organizing health promotion activities about using smartphones in a controlled manner at home and on campus.

This study showed that $36 \%$ of undergraduates had used a smartphone while driving a car or scooter and that women were more likely than men to use a smartphone while driving a car or scooter. Evidence has revealed that using a cell phone while driving is associated with a four-fold increase in crash risk [46] or increase in the occurrence of motorcycle accidents. [37] Although the Taiwanese government has established regulations to prohibit smartphone use while driving to prevent accidents [14], our study data indicate that the regulations do not prevent young people, particularly women, from continuing to use their smartphones while driving, possibly because of poor legal enforcement. Therefore, obeying the regulations could be promoted on 
campus by reminding students not to use a smartphone while driving a car or scooter.

According to the study results, students studying in different colleges had different levels of smartphone dependence; this finding is consistent with those of previous studies [38, 41]. In this study, students from colleges of Management and Business had significantly higher scores of smartphone dependence than those from other colleges. A possible reason for this difference could be that Management and Business students are often required to use electronics products, such as computers, smartphones, and tablet computers for their future business activities and career; consequently, they would have higher smartphone dependence. By contrast, Medical Science and Engineering students had lower smartphone dependence, possibly because they may be more aware of the adverse health effects of prolonged smartphone use. Such information on the responsible use and avoidance of dependence on new technology might be included in a school course, particularly for Management and Business students.

\section{Limitations and Future Research}

This study used a cross-sectional design to investigate the predictive factors of smartphone use and dependence among undergraduates. However, this study did not include all possible factors, such as social stress in student life and the locus of control and personality type, influencing smartphone use patterns and dependence. Future studies are required to investigate the extent to which psychosocial factors contribute to smartphone use and dependence among undergraduates. Furthermore, the study methodology was unable to verify the cause and effect among factors. An interventional approach with a longitudinal design is recommended for use in future studies to examine the cause and effect of smartphone use, smartphone dependence, and behavioral changes with smartphone use patterns. Thus, effective strategies for preventing smartphone dependence can be developed. Because of limited funds and manpower, only four universities were included. Expanding the sample size by using random sampling or big data is recommended for future studies to obtain more accurate information regarding smartphone use patterns, so that the findings can be applied to other undergraduates and more efficient strategies can be developed to reduce and prevent smartphone dependence. Furthermore, the self-administered structured questionnaire of smartphone dependence was used only by the undergraduates; consequently, common method bias may be a potential limitation. The opinions of parents and peers should be included 
in future studies to obtain more objective results of smartphone dependence among undergraduates.

\section{Conclusion}

Because of the efficiency and convenience of smartphones, an increasing number of people rely on them. In particular, smartphones have constituted a part of the lifestyle of undergraduates. In this circumstance, smartphone overuse may cause adverse health effects. The present study provides a basis for the direction of future studies in efforts to prevent or reduce the negative effects caused by this new technology. Importantly, the present study provides foundation for developing multi-faceted strategies designed to discourage the overuse of smartphones among undergraduates.

\section{Acknowledgements}

We would like to express the gratitude to the participating universities and students for their efforts.

\section{References}

[1] Aoki, K., and Downes, E. J. (2003). An analysis of young people's use of and attitudes toward cell phones. Telematics and Informatics, 20(4), 349-364.

[2] Diagnostic, A. P. A. (2000). statistical manual of mental disorders DSMIV-TR, American Psychiatric Association Task Force on DSM-IV.

[3] Balakrishnan, V., and Raj, R. G. (2012). Exploring the relationship between urbanized Malaysian youth and their mobile phones: A quantitative approach. Telematics and Informatics, 29(3), 263-272.

[4] Barometer, C. (2015). Trended data. Available at: https://www.consum erbarometer.com/en/

[5] Baron, N. S., and Campbell, E. M. (2012). Gender and mobile phones in cross-national context. Language Sciences, 34(1), 13-27.

[6] Beranuy, M., Oberst, U., Carbonell, X., and Chamarro, A. (2009). Problematic Internet and mobile phone use and clinical symptoms in college students: The role of emotional intelligence. Computers in human behavior, 25(5), 1182-1187. 
[7] Bianchi, A., and Phillips, J. G. (2005). Psychological predictors of problem mobile phone use. CyberPsychology \& Behavior, 8(1), 39-51.

[8] Brenner, V. (1997). Psychology of computer use: XLVII. Parameters of Internet use, abuse and addiction: the first 90 days of the Internet Usage Survey. Psychological reports, 80(3), 879-882.

[9] Brown, K., Campbell, S. W., and Ling, R. (2011). Mobile phones bridging the digital divide for teens in the US. Future Internet, 3(2), 144-158.

[10] Çağan, Ö., Ünsal, A., and Çelik, N. (2014). Evaluation of college students' the level of addiction to cellular phone and investigation on the relationsship between the addiction and the level of depression. Procedia-Social and Behavioral Sciences, 114, 831-839.

[11] Chang, K. P. (2009). A Study on Parental Rearing Attitude, Family Mental Environment, and Teenager's Internet Addiction. Journal of Family Education and Counseling, 6, 111.

[12] Chang, Y. M., et al., (2012). The application of single-session webbased counseling model to college internet addicts: Changes of symptoms and effectiveness. Journal of Educational Practice and Research, 25(1), 131-162.

[13] Chen, C. Y., et al., (2014). Smartphone addiction and related factors among university students in Chiayi County. Health Promotion and Health Education Journal, 37, 47-70.

[14] China, L.R.D.o.t.R.o. (2015). Road traffic management and penalty Act.; Available at: http://law.moj.gov.tw/LawClass/LawAll.aspx?PCode=K00 40012

[15] China, T.B.A.o.R.o. (2013). The Bankers association of Republic Of China and visa and AIESEC work together to promote financial education and financial education activities to help college students in Taiwan to establish proper financial management concepts necessary for future. Available at: http://www.ba.org.tw/Notice $/$ Index?page $=4 \&$ type $=$ LatestNew

[16] Chu, C. P., Lin, C. J., and Chen, K. W. (2008). A survey research on the behaviors of internet usage, addiction, and self-reduction efficacy of high school students. Journal of Health Management, 6(1), 73-94.

[17] Chuang, C. K., Zhou, J. C., and Lee, C. P. (2014). The study of facebook involvement, personality traits and internet interpersonal on the influence of internet addiction. Journal of Data Analysis, 9(3), 165-186.

[18] Coogan, K., and Kangas, S. (2001). Young People and Communication Acrobatics. The Mobile Phone and Internet Culture of Young People, $16-18$. 
[19] Corporation, I. D. (2013).Worldwide mobile phone market forecast to grow $7.3 \%$ in 2013 driven by 1 billion smartphone shipments. Available at: http://www.reuters.com/article/2013/09/04/ma-idc-idUS nBw045542a+100+BSW20130904

[20] Directorate-General of Budget, A.a.S., Executive Yuan, R.O.C. (2013). Average family income and expenditure per household by areas. Available at: http://win.dgbas.gov.tw/fies/index.asp.

[21] Donner, J. (2007). The rules of beeping: exchanging messages via intentional "missed calls" on mobile phones. Journal of computer-mediated communication, 13(1), 1-22.

[22] Dresler-Hawke, E., and Mansvelt, J. (2008). Mobile phones: Enhancing social communication in young adult's lives. In Presentation at the Australian and New Zealand Marketing Academy Conference, 1-7.

[23] Feng, C. Y. (2004). The empirical study of the relationship between consumption motive and consumption behavior by youngsters for the cellular phone., The University of Tamkang: Taipei.

[24] Foundation, K.C.E. (2011). The adolescents phone addiction anxiety up to $93 \%$. Available at: http://www.cna.com.tw/news/FirstNews/20110517 0042-1.aspx

[25] Fu, A. H., Chung, Y. C. and Lin, H. S. (2013). The relationships between vocational high school students' internet addiction and health behavior. Human Ecology: Vision Insight, 9, 1-20.

[26] Gillwald, A. (2005). Towards an African e-Index. Household and Individual ICT Access and Usage in 10 African Countries.

[27] Griffiths, M. (1995). Technological addictions. In Clinical Psychology Forum. DIVISION OF CLINICAL PSYCHOLOGY OF THE BRITISH PSYCHOL SOC.

[28] Griffiths, M. (1998). Internet addiction: does it really exist?.

[29] Hong, F. Y., et al., (2013). Research on a college students' mobile phone usage and usage motivation. Journal of School Health Nursing, 23, 77-99.

[30] Jamal, A., et al., (2012). Patterns of use of 'smart phones' among female medical students and self-reported effects. Journal of Taibah University Medical Sciences, 7(1), 45-49.

[31] Kamibeppu, K., and Sugiura, H. (2005). Impact of the mobile phone on junior high-school students' friendships in the Tokyo metropolitan area. Cyberpsychology \& Behavior, 8(2), 121-130. 
[32] Korpinen, L., and Pääkkönen, R. (2011). Physical symptoms in young adults and their use of different computers and mobile phones. International Journal of Occupational Safety and Ergonomics, 17(4), 361-371.

[33] Krejcie, R. V., and Morgan, D. W. (1970). Determining sample size for research activities. Educational and psychological measurement, 30(3), 607-610.

[34] Kwon, M., Kim, D. J., Cho, H., and Yang, S. (2013). The smartphone addiction scale: development and validation of a short version for adolescents. PloS one, 8(12), e83558.

[35] Liao, W. I. (2008). A study of teenagers' use of the mobile phones and factors of addiction. National Chiayi University: Chiayi City.

[36] Lien, T. C. (2007). A study of the effectiveness in applying solutionfocused group counseling to internet-addicted adolescents. Journal of Counseling \& Guidance, 17, 39-64.

[37] Lin, C. C. (2004). Epidemiological survey of motorcycle accidents among college students in City. Kaohsiung medical university: Kaohsiung.

[38] Lin, H. T. (2012). A comparative study on the personal traits of university students with internet and mobile phone addiction. The University of Taipei.: Taipei.

[39] Lin, M. H. (2012). Studies on teenagers' mobile-phone-use behavior and its dependence: A case study of junior high school students in Taoyuan County. The University of Yuan Ze: Taoyuan.

[40] Lin, M. P., Ting, C. K., Lai, Y. C., and Ko, H. C. (2005). Internet addiction among college students with adult attachment styles. Formosa Journal of Mental Health, 18, 93-119.

[41] Lin, P. Y., et al., (2013). The study of smartphone's impact on the national college students' leisure behavior. Journal of Recreation Sport and Health Promotion, 4, 17-33.

[42] Ling, R., and Yttri, B. (2002). 10 Hyper-coordination via mobile phones in Norway. Perpetual contact: Mobile communication, private talk, public performance, 139.

[43] Lu, T. H. (2011). The mental model of smartphones. The Medical University of Kaohsiung: Kaohsiung.

[44] Lynn, M. R. (1986). Determination and quantification of content validity. Nursing research.

[45] Madden, M., and Lenhart, A. (2009). Teens and distracted driving: Texting, talking and other uses of the cell phone behind the wheel. 
[46] McEvoy, S. P., Stevenson, M. R., McCartt, A. T., Woodward, M., Haworth, C., Palamara, P., and Cercarelli, R. (2005). Role of mobile phones in motor vehicle crashes resulting in hospital attendance: a case-crossover study. Bmj, 331(7514), 428.

[47] Ministry of Economic Affairs, T., R.O.C. Smart internet. (2011). White paper on industrial technology. Available at: http://investtaiwan.nat.gov. tw/doc/itech/2012/2011_2_1_1.pdf

[48] Ministry of Education, T., R.O.C. (2012). The number of students in university- categorized by gender and age.Available at: http://www.edu.tw/pages/detail.aspx?Node=3973\&Page=20272\&WID $=31 \mathrm{~d} 75 \mathrm{a} 44-$ efff-4c44-a075-15a9eb7aecdf

[49] Ministry of Education Taiwan, R.O.C. (2014). Note kids' internet behavior: The effort among family, school and community. Available at: http://epaper.edu.tw/papago.aspx?period_num $=634$

[50] Morahan-Martin, J., and Schumacher, P. (2000). Incidence and correlates of pathological Internet use among college students. Computers in human behavior, 16(1), 13-29.

[51] Munro, B. H. (2005). Statistical methods for health care research. Lippincott Williams \& Wilkins.

[52] National Development Council, T., R.O.C. (2010). Smart handheld devices. Available at: http://www.ndc.gov.tw/dn.aspx?uid=8946

[53] Nemme, H. E., and White, K. M. (2010). Texting while driving: Psychosocial influences on young people's texting intentions and behaviour. Accident Analysis \& Prevention, 42(4), 1257-1265.

[54] Oulasvirta, A., Rattenbury, T., Ma, L., and Raita, E. (2012). Habits make smartphone use more pervasive. Personal and Ubiquitous Computing, 16(1), 105-114.

[55] Parks, M. R., and Floyd, K. (1996). Making friends in cyberspace. Journal of computer-mediated communication, 1(4), JCMC144.

[56] Raento, M., Oulasvirta, A., and Eagle, N. (2009). Smartphones: An emerging tool for social scientists. Sociological methods \& research, 37(3), 426-454.

[57] Ray, C. M., Sormunen, C., and Harris, T. M. (1999). Men's and women's attitudes toward computer technology: A comparison. Information Technology, Learning, and Performance Journal, 17(1), 1.

[58] Shieh, L. C. (2004). The internet use and internet addiction of adolescence. Journal of National Taichung Teachers College, 18(2), 19-44. 
[59] Sánchez-Martínez, M., and Otero, A. (2009). Factors associated with cell phone use in adolescents in the community of Madrid (Spain). CyberPsychology \& Behavior, 12(2), 131-137.

[60] Tai, H. C., Yang, M. S., and Yen, C. F. (2004). Internet addiction and its impact on physical and mental health among adolescents in Southern Taiwan. Tzu Chi Medical Journal, 16(4), 241-248.

[61] Takao, M., Takahashi, S., and Kitamura, M. (2009). Addictive personality and problematic mobile phone use. CyberPsychology \& Behavior, 12(5), 501-507.

[62] Tsai, Y. L., Tsai, C. S., and Chuo, J. M. (2012). Impact of facebook game's involvement and addiction on physical and mental health and learning attitude: A case study from university students in Madou. Journal of Sport and Recreation Research, 16(4), 16-38.

[63] Van Deursen, A. J., Bolle, C. L., Hegner, S. M., and Kommers, P. A. (2015). Modeling habitual and addictive smartphone behavior: The role of smartphone usage types, emotional intelligence, social stress, selfregulation, age, and gender. Computers in human behavior, 45, 411420.64.

[64] Walsh, S. P., White, K. M., and Young, R. M. (2008). Over-connected A qualitative exploration of the relationship between Australian youth and their mobile phones. Journal of adolescence, 31(1), 77-92.

[65] Walsh, S. P., White, K. M., Cox, S., and Young, R. M. (2011). Keeping in constant touch: The predictors of young Australians' mobile phone involvement. Computers in Human Behavior, 27(1), 333-342.

[66] Walther, J. B. (1992). Interpersonal effects in computer-mediated interaction: A relational perspective. Communication research, 19(1), 52-90.

[67] Wei, H. I., Li, J. J., and Wang, W. W. (2006). Risk Factors and Delinquent Behavior Associated with Internet Addiction among High School Students: A Pilot Study in Taichung. Journal of National Taichung University: Education, 20(1), 101-102.

[68] Wilska, T. A. (2003). Mobile phone use as part of young people's consumption styles. Journal of consumer policy, 26(4), 441-463.

[69] Yang, M. E. (2002). Internet and sport coaches. Sports Coaching Science, $1,120-127$.

[70] Yang, S. C., and Tung, C. J. (2007). Comparison of Internet addicts and non-addicts in Taiwanese high school. Computers in Human Behavior, 23(1), 79-96. 


\section{Nae-Fang Miao et al.}

[71] Yen, C. F., Tang, T. C., Yen, J. Y., Lin, H. C., Huang, C. F., Liu, S. C., and Ko, C. H. (2009). Symptoms of problematic cellular phone use, functional impairment and its association with depression among adolescents in Southern Taiwan. Journal of adolescence, 32(4), 863-873.

[72] Young, K. S. (1998). Internet addiction: The emergence of a new clinical disorder. Cyberpsychology \& behavior, 1(3), 237-244.

\section{Biographies}

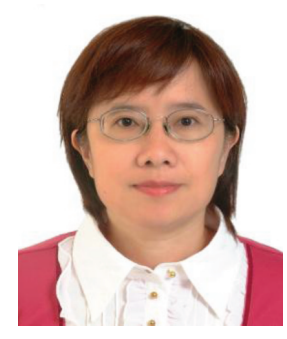

Nae-Fang Miao, RN, PhD, is an Assistant Professor in the Post-Baccalaureate Program in Nursing at Taipei Medical University, Taipei City, Taiwan. Her main research topics are substance misuse by adolescents, community health nursing, and evaluation of interventions for the promotion of a healthy life for adolescents.

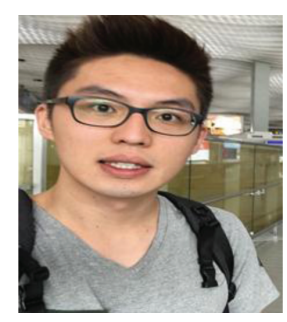

Cheng-Jin Lin, MSN, graduated from the Department of Healthcare Administration, Asia University, Taichung, Taiwan. He is a researcher in the Master Program in Long-term Care at Taipei Medical University, Taipei, Taiwan. His main research interest is health care administration. 


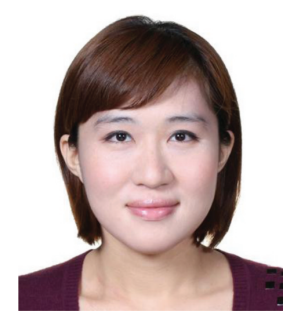

Ching-Lien Cheng, RN, MSN, graduated from the Graduate Institute of Nursing at Taipei Medical University, Taipei City, Taiwan. She is a clinical head nurse in the Cathay General Hospital, Taipei City, Taiwan. Her main research interest is community health nursing.

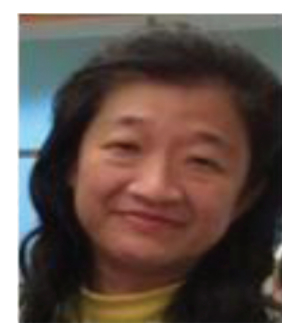

Yu-Ling Hsiao, RN, PhD, is an Assistant Professor in the School of Nursing at Fu Jen Catholic University, New Taipei City, Taiwan. Her main research topics are community health nursing and health promotion.

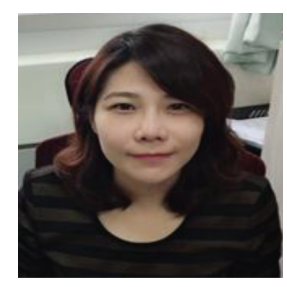

I-Hui Chen, $\mathrm{RN}, \mathrm{PhD}$, is an Assistant Professor in the Master Program in Long-term Care at Taipei Medical University, Taipei, Taiwan. Her main research interests are community health nursing, health promotion, elder care and long-term care. 
